\title{
A systematic review on teaching fraction for understanding through representation on Web of Science database using PRISMA
}

\author{
Rosmawati Mohamed, Munirah Ghazali and Mohd Ali Samsudin \\ School of Educational Studies, Universiti Sains Malaysia, Penang, Malaysia
}

Through a search executed on Web of Science database with general keywords pertaining to 'teaching fractions' or 'understanding fractions' and 'representation', this study utilized PRISMA's procedure in analysing previously published articles. This review reveals seven articles in inclusion criteria and seventeenth articles in exclusion criteria with reasons. The included articles were reviewed for (a) studies characteristics, (b) instructional focus, (c) representation elements: real-world situation, manipulative aids, pictures, spoken and written symbols, and (d) the outcomes of each study. The metadata was analysed to organise the outcomes. Most of these articles focus on grade 3 and above and Western countries' urban area. The result indicates most studies emphasize both conceptual and procedural understandings. Multi representations utilize sequential or parallel concept related to fractions improve students' knowledge, particularly in understanding fractions. Meanwhile, developing fraction learning through multiple explicit representations at the initial Grade level of fraction instruction is for elementary school. However, less attention has been given to explicit representations in learning fractions at such a level.

\author{
Article Details \\ LUMAT General Issue \\ Vol 9 No 1 (2021), 100-125 \\ Received 30 October 2020 \\ Accepted 2 February 2021 \\ Published 23 February 2021 \\ Pages: 26 \\ References: 51 \\ Correspondence: \\ rosmawati2636@gmail.com \\ https://doi.org/10.31129/ \\ LUMAT.9.1.1449
}

Keywords: teaching fractions, representation, review, elementary school, PRISMA

\section{Introduction}

Understanding fractions has been a global issue until today due to its importance as a foundation for mathematical knowledge and skills (National Council of Teachers of Mathematics [NCTM], 2007). Fractions' understanding supports the knowledge of advanced concepts and procedures at higher levels (Aliustaoğlu, Tuna, \& Biber, 2018; Bailey et al., 2015; Siegler, Thompson, \& Schneider, 2011). Notably, the most recent challenges in understanding fractions are closely related to cognitive bias (Hacker, Kiuhara, \& Levin, 2019; Krowka \& Fuchs, 2017; Liu, 2017). Provided that failure of some students in understanding the concepts and procedures of fractions indicates diverse cognitive abilities between the students, it becomes the factor for students' difficulties in solving problems, especially those involving fraction magnitudes. As a result, they fail to differentiate between the whole number and ratio representations (Hoch et al., 2018) during problem-solving. 
As highlighted by Behr, Lesh, Post, and Silver (1983) almost 40 years ago, strong fraction knowledge is vital for algebraic understanding (Booth, Newton, \& TwissGarrity, 2014). This argument remains relevant today, attracting current researchers' attention (Braithwaite et al., 2019; Fitzsimmons, Thompson \& Sidney, 2020), mostly when fractions frequently misunderstood with whole numbers (Siegler et al., 2011). For example, students mistakenly believe that $\frac{1}{8}$ is large and $\frac{1}{2}$ is small (Hamdan \& Gunderson, 2017). Therefore, effective strategies are essential to enhance their foundation on fractions (Siegler et al., 2011) that emphasize symbol for fraction means a single number and not two different whole numbers (Reinhold, Hoch, Werner, Richter-Gebert, \& Reiss, 2020). For example, the following list of numbers: $2, \frac{2}{7}$ means there are two numbers whereby students frequently assume that as three numbers.

Teaching fractions at early Grade level begins with part-whole and measurement interpretations. The part-whole is a combination of two single words; part and whole. The whole refers to all equal parts of a single object; for example, a cake has six equal parts) or all subsets of a set of objects; for example, three cakes with the same size and shape); whereby, the part refers to one or more than one equal parts. Therefore, the part-whole is defined as one or more equal parts of a single object; for example, two of six equal parts of a cake, or a set of a group of objects; for example, one of three cakes. Typically, understanding the part-whole is represented using an area model whereby one or more parts of a 2-dimensional shape is shaded, coloured or pasted with small pieces of paper to distinguish the part/ parts from other parts. This area model strategy is commonly used by most teachers from Western or Eastern countries to interpret part-whole through the story of sharing (Fuchs et al., 2016).

Various representation methods executed in previous studies (Flores et al., 2018; Simon et al., 2018) were conducted in the United States which include materials manipulation (e.g., fraction block, fractions disc, fractions cards, sheets of paper or virtual task), real-life context (e.g., problem situation, problem scenario), visual representation using pictures of various dimensional objects (e.g., one-dimensional number line, two-dimensional circle and rectangle, and three-dimensional cylinder, cube, cuboid, and sphere), verbalization of written form whether using words (e.g., one over two, half, quarter), numbers (e.g., o, $1, \frac{1}{2}, \frac{2}{3}, \frac{3}{5}$ ), or even spoken (e.g., group discussions, read aloud word problems).

The studies involve various representations not restricted to the topic of fractions. For example, Tajudin and Chinnappan (2016) emphasized the relationship between real-world problems, manipulative, pictures and symbolic representations with 
higher-order tasks. Whereas, Supandi, Waluya, Rochmad, Suyitno, and Dewi (2018) highlighted the connection between spoken, written symbols and visual representations for different topics. On the other hand, a large-scale study conducted by Van Steenbrugge, Remillard, Verschaffel, Valcke, and Desoete (2015) in Flanders for 342 Grade 4 students focuses on the connection between the representation for fractions topic. Meanwhile, Flores, Hinton, and Taylor (2018) in the United States studied 17 Grade 3 to Grade 5 students using Concrete-Representational-Abstract (CRA), in which a synchronised use of different approaches was considered to improve students' understanding on fractions. Additionally, the students were provided with the opportunity to utilize manipulated object at a concrete level and subsequently at representation level by drawing a picture of previously used object to solve numerical or word problems (Flores et al., 2018). However, inadequate emphasis was placed on explicit representation of fractions in elementary school. Therefore, this study focuses on analysing multiple fraction learning representations among elementary students.

The purpose of this review article is to extend previously reviewed recommendations (Roesslein \& Codding, 2019) and specifies how representation elements originated by Behr et al. (1983) and Zhu and Fan (2007) are interpreted and defined for elementary school level. The research questions are:

1. What are the study characteristics adapted in each study?

2. What is the instructional focus of fractions adapted in each study?

3. What are the representation elements of fractions adapted in each study?

4. What are the outcomes of each study?

\section{Theoretical framework}

Classical perspective of various representations originated by Bruner's theory begins with enactive (manipulative skills) followed by iconic (visual representations); then, to symbolic (using mathematical formulas) learning. These three levels are also known as discovery learning. Firstly, the enactive level is a concrete operation level; whereby, students learn by touching, feeling and manipulative skills. Secondly, the iconic level is the visualization stage; whereby, students develop the ability to formulate and explain concrete situations. On the other hand, symbolic or abstract level allows students to organize information in mind and relate the concepts together (Bruner, 1971). 
Later, Lesh (1979) expanded Bruner's (1971) hierarchical idea; whereby iconic mode corresponds with manipulative aids and picture, whereas symbolic mode involves spoken and written symbols. Manipulative aids, picture, spoken and written symbols are important elements to explain real-life situations. Different elements may be used in several different ways depend on the situations. These elements support students' meaningful transformation from concrete learning operation into abstract level.

It is impossible to determine manipulative material is appropriate for all types of students in all situations since they have different intelligence and abilities (Behr et al., 1983). Therefore, Behr et al. (1983) proposed interactive representational system model. The model does not only represent all element representations such as manipulative aids, picture, spoken, written symbols and real-world situations, but also emphasizes interactions between elements. Through this model, mathematical problems can be solved in several ways; (a) translate real situations into multiple representations, (b) change or control representational systems to make decisions or predictions, (c) redirect decisions to real situations (Behr et al., 1983).

Later, Miller and Hudson (2007) renamed Bruner's idea on enactive, iconic and symbolic representation to concrete, representational and abstract (CRA) instructional sequence utilised by recent studies (Flores et al., 2018; Hwang et. al., 2018). Zhu and Fan (2007) introduced problem representation in pure mathematics (symbolic number), written, verbal and visual representations. However, they did not mention about manipulative aids; even when they discussed real-life situations. Therefore, both Zhu and Fan's (2007) and Behr et al.'s (1983) ideas were synthesized in current study to form framework for analysing fraction representations.

\section{Methodology}

This section elaborates five main sub-sections such as PRISMA, resources, systematic review process for article selection, data abstraction, analysis employed in current study and coding procedures. 


\subsection{Preferred Reporting Items for systematic reviews and Meta-Analyses (PRISMA)}

Preferred Reporting Items for systematic reviews and Meta-Analyses (PRISMA) was utilised to identify PRISMA's characteristics and its utilization. There are four hierarchical phases (Liberati et al., 2009), and they are organized in flow diagram as presented in Figure 1.

\subsection{Resources}

Most common database, Web of Science (SCI) was utilized for it provides wide coverage of published articles in Science and Social Sciences fields. SCI is published by Clarivate Analytics and has indexed over 8700 journals (Burnham, 2006).

\subsection{Systematic review process for the articles' selection}

The first phase is identification process of which the authors enrich main keywords using several steps so that articles from the database could be retrieved as many as possible. Using Web of Science formatting in April 2020, the following search strings were generated:

$\mathrm{TS}=($ ( "teaching fractions" OR "teaching rational number" OR "learning fractions" OR "learning rational number" OR "fraction instruction" OR "fraction intervention" OR "understand* fraction" OR "fraction knowledge" OR "fraction pedagogy" OR "fraction abilit*" OR "fraction skill") AND ( "representation" OR "modelling" OR "manipulative" OR "real life" OR "picture" OR "symbol" ))

The second phase is screening. At this phase, articles were included or excluded based on criteria agreed by the authors before generating the articles using the database. After the articles were generated, eleven non-related articles were identified and then removed. Hence, only thirteen articles were attained for review. Further screening was conducted, and five more articles were removed as they did not match the criteria for the included articles. Eventually, eight articles with eligible articles were included in the review.

The third phase is eligibility, the process where the authors thoroughly examined those eight articles by reading the titles, abstract, result and discussion to ensure they met the inclusion criteria; thus, serve current research objectives. It was unanimously agreed that one article needed to be rejected as the article focuses on textbooks 
analysis. As a result, only seven articles were deemed suitable to further data abstraction and analysis. Figure 1 shows a flow diagram of identification, screening, eligibility and included criteria as suggested in Shaffril, Abu Samah, Samsuddin, and Ali (2019).

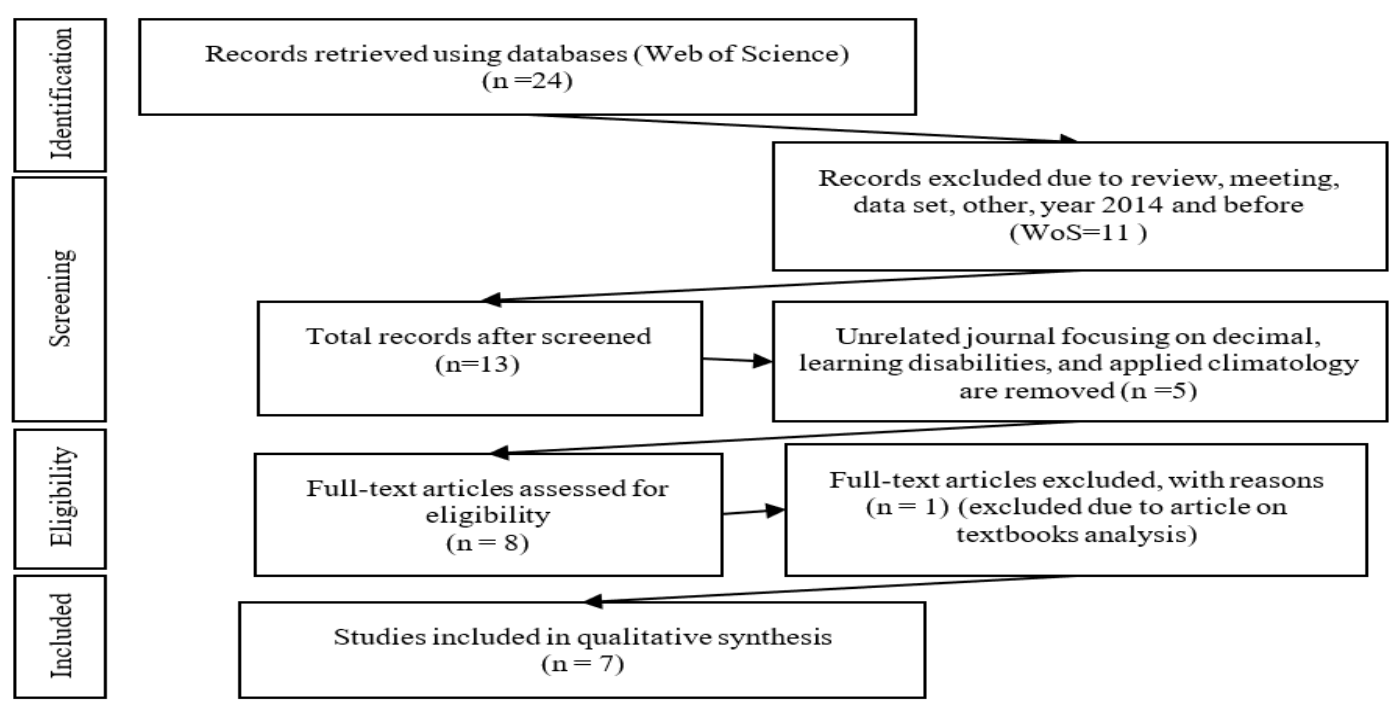

Figure 1. Flow Diagram of identification, screening, eligibility and included criteria.

\subsection{Data abstraction and analysis}

Thematic analysis was used to seek suitable themes and categories through several stages. First, the authors analysed seven selected articles on its abstract, methodology, results and discussions in order to extract important ideas in answering the research questions. Next, possible codes were listed according to study characteristics, instructional focus, representation elements and the outcomes of each study.

Then, five categories of study characteristics were identified such as participants, grade, ethnicity, urbanicity and location. Meanwhile, two categories of instructional focus were distinguished, namely procedural knowledge and conceptual knowledge. Five more categories of fraction representations were found and those were real-world situations, manipulative aids, pictures, spoken and written symbols. Study outcome categories were coded as concrete, representational and abstract (CRA), representational and abstract (RA) and concrete, representational (CR) (Table 5).

Model representational system by Behr et al. (1983) is referred to develop themes and categories for representation of fractions (inductive process). Under the category of written symbols, the author developed two sub-categories, namely words and numbers. The intention is to specify how representation elements originated by Behr 
et al. (1983) were interpreted and defined in this review article. Therefore, the operational definitions for each category of instructional focus and representations elements are listed in Table 2.

The authors closely read the articles' full text to identify the codes for study characteristics, instructional focus, representation elements and the outcomes for each study. Any arguments regarding the suitability of coding for each category is finalized with the second and third author as they are experts and senior lecturers in Mathematics and Science Education. Appropriate terms used for each category and coding arrangement in the respective categories were also established. Those categories and codes are highlighted in Table 2 to Table 5. Metadata analysis of the instructional focus and representation elements were re-coded dichotomously, $\mathrm{o}$ and 1 (Chan, Leu \& Chen, 2007; Ni, 2000) whereby 1 stands for appear and o for does not appear in the article (Table 5).

\subsection{Coding procedures}

\section{Characteristics of the studies}

Characteristics of the studies were coded into five categories including participants, grade, ethnicity, urbanicity and location. For certain studies of which the characteristics are ambiguous or not clearly presented, dash symbol '-‘ was utilized.

\section{Participants and Grade.}

A total of 1606 students participated across those seven studies involving elementary students with different abilities from Grade 1 until Grade 6. Five studies utilized multi-Grade students, (Begolli, Booth, Holmes, \& Newcombe, 2020; Degrande, Van Hoof, Verschaffel, \& Van Dooren, 2017; Flores et al., 2018; Hamdan \& Gunderson, 2017; Resnick et al., 2016) and two studies included single Grade students (Kaminski \& Sloutsky, 2020; Liu, 2017). One article employed longitudinally study on mathematical development; whereby students' progress were monitored through Grade 3 to Grade 6 (Resnick et al., 2016).

\section{Ethnicity, urbanicity and location.}

Four studies encompassed of ethnically or racially diverse student samples (Begolli et al., 2020; Flores et al., 2018; Hamdan \& Gunderson, 2017; Resnick et al., 2016) and two studies applied ethnically or racially homogeneous student samples (Kaminski \& 
Sloutsky, 2020; Liu, 2017). Study from Degrande et al. (2017) provides no explicit information about ethnically or racially student samples used. In addition, five studies provide information about school setting urbanicity; whereby suburban $(n=1)$ (Kaminski \& Sloutsky, 2020), urban ( $\mathrm{n=3}$ ) (Begolli et al., 2020; Liu, 2017; Hamdan \& Gunderson, 2017) and rural ( $n=1)$ (Flores et al., 2018). Five studies took place in United States and one study was conducted in Belgium and China, respectively. Generally, the studies were carried out mostly in the Western countries. Table 1 presents the characteristics of the studies.

Table 1. Characteristics of the studies

\begin{tabular}{|c|c|c|c|c|c|}
\hline Study & Participants & Grade & Ethnicity & Urbanicity & Location \\
\hline $\begin{array}{l}\text { Kaminski \& } \\
\text { Sloutsky (2020) }\end{array}$ & $\begin{array}{l}413 \text { teachers } \\
29 \text { (students) }\end{array}$ & $1^{\text {st }}$ & White & suburban & $\begin{array}{l}\text { United } \\
\text { States }\end{array}$ \\
\hline $\begin{array}{l}\text { Begolli, Booth, } \\
\text { Holmes, \& } \\
\text { Newcombe (2020) }\end{array}$ & 565 students & $1^{\text {st }}-6^{\text {th }}$ & $\begin{array}{l}62 \% \text { White, 28\% Black, 5\% } \\
\text { Hispanic, 3\% Asian, and 2\% } \\
\text { multiracial }\end{array}$ & urban & $\begin{array}{l}\text { United } \\
\text { States }\end{array}$ \\
\hline $\begin{array}{l}\text { Flores, Hinton \& } \\
\text { Taylor (2018) }\end{array}$ & $\begin{array}{l}17(7 \mathrm{~F}, 10 \mathrm{M}) \\
\text { students } \\
\text { LA (score } \\
\leq 65 \%)\end{array}$ & $3-5^{\text {th }}$ & $\begin{array}{l}6 \text { white, } 9 \text { African American, } \\
2 \text { Latino }\end{array}$ & rural & $\begin{array}{l}\text { United } \\
\text { States }\end{array}$ \\
\hline Liu (2017) & $\begin{array}{l}1 \text { teacher } \\
75 \text { students }\end{array}$ & $4^{\text {th }}$ & Chinese & urban & China \\
\hline $\begin{array}{l}\text { Degrande, Hoof, } \\
\text { Verschaffel, \& Van } \\
\text { Dooren (2017) }\end{array}$ & 279 students & $\begin{array}{l}5^{\text {th }} \\
\text { and } \\
6^{\text {th }}\end{array}$ & - & - & $\begin{array}{l}\text { Belgium } \\
\text { (Flanders) }\end{array}$ \\
\hline $\begin{array}{l}\text { Hamdan \& } \\
\text { Gunderson (2017) }\end{array}$ & 114 students & $\begin{array}{l}2^{\text {nd }} \\
\text { and } \\
3^{\text {rd }}\end{array}$ & $\begin{array}{l}\text { 67\% African American, } 23.9 \% \\
\text { Caucasian, } 4.7 \% \text { Asian, } 1.9 \% \\
\text { Hispanic, } 2.8 \% \text { other or } \\
\text { multiple races }\end{array}$ & urban & $\begin{array}{l}\text { United } \\
\text { States }\end{array}$ \\
\hline $\begin{array}{l}\text { Resnick, Jordan, } \\
\text { Hansen, Rajan, } \\
\text { Rodrigues, Siegler } \\
\text { \& Fuchs (2016) }\end{array}$ & 517 students & $\begin{array}{l}3^{\text {rd }} \\
4^{\text {th }} \\
5^{\text {th }} \\
6^{\text {th }}\end{array}$ & $\begin{array}{l}\text { 51.9\% White, } 40.0 \% \text { Black, } \\
5.7 \% \text { Asian/Pacific Island, and } \\
2.5 \% \text { American } \\
\text { Indian/Alaskan Native; } 17.7 \% \\
\text { of children identified their } \\
\text { ethnicity as Hispanic. }\end{array}$ & - & $\begin{array}{l}\text { United } \\
\text { States }\end{array}$ \\
\hline
\end{tabular}

\section{Instructional focus}

For instructional focus, studies were coded into two categories such as procedural knowledge and conceptual knowledge. The followings are operational definitions for conceptual and procedural knowledge according to Anderson et al. (2001, p. 46), 
Misquitta (2011) and Roesslein and Codding (2019):

1. Conceptual focus involves the effort of making inter-relationships (Anderson, et al., 2001, p. 46) by comparing fractions on number line and utilizing skills to answer word problems (Misquitta, 2011; Roesslein \& Codding, 2019).

2. Procedural focus encompasses strategy to aid problem solving (Anderson, et al., 2001, p. 46) by employing algorithms (Misquitta, 2011) computation (Roesslein \& Codding, 2019), counting, writing, reading, drawing, shading, matching or labelling.

\section{Representation elements}

The representation elements were coded according to five categories namely realworld situation, manipulative aids, pictures, spoken and written symbols. Meanwhile, written symbols were also coded into subcategories which are words and numbers. These categories are based on Behr et al. (1983) model of interactive representational system. The definition for each category was applied based on various literature as follows:

1. Real-world situation indicates that contextual problems allow the application of real-world context in mathematical tasks, assessments or activities to represent the problems (Masingila \& Moellwald, 1993); and can be explained in terms of educational, personal, occupational or public domain (Council of Europe., 2011, p. 48).

2. Manipulative aids indicate that concrete object can be manipulated or utilized without any manipulation (Istiandaru, Istihapsari, Prahmana, Setyawan, Hendroanto, 2017) to demonstrate the procedure to solve problem (e.g., sheets, task paper, fractions cards, blocks) (Zhu \& Fan, 2007) in terms of educational, personal, occupational or public domain (Council of Europe., 2011, p. 48).

3. Pictures indicate that the application of monochromatic or colourful visual representation can also be applied such as modelling or diagram based on the information given in the problem (e.g., circle, rectangle, square, triangle and number line) (Zhu \& Fan, 2007); and are connected to fraction interpretations of part-whole, measurement and part of a set.

4. Spoken indicates that teacher's, students', experimenter's or researcher's reading, speaking, talking or utterance which involves thinking aloud, reading 
problem situation, teaching or discussing for problem comprehension or solving (Roesslein \& Codding, 2019)

5. Written symbols are words that suggest students to use words representing quantities or problem situation (e.g., one over two, one part and two parts) (Zhu \& Fan, 2007; Pimm, 1995). Number specifies that students use numbers to represent quantities in the problem (e.g., 0.5, o, 1 and $\frac{1}{7}$ ) (Zhu \& Fan, 2007; Pimm, 1995).

Table 2 summarises operational definitions of instructional focus and representation elements.

Table 2. Operational definitions of instructional focus and representation elements.

\begin{tabular}{|c|c|c|c|c|c|c|}
\hline Procedural & Conceptual & $\begin{array}{l}\text { Real-world } \\
\text { situation }\end{array}$ & $\begin{array}{l}\text { Manipulative } \\
\text { aids }\end{array}$ & Pictures & Spoken & $\begin{array}{l}\text { Written } \\
\text { symbols } \\
\text { (words) }\end{array}$ \\
\hline $\begin{array}{l}\text { Make } \\
\text { Cut } \\
\text { Fold } \\
\text { Explore } \\
\text { pattern } \\
\text { Label } \\
\text { Shade } \\
\text { Glue } \\
\text { Follow } \\
\text { Make } \\
\text { Name } \\
\text { Writing } \\
\text { Draw } \\
\text { Matching } \\
\text { Use arrow } \\
\text { keys } \\
\text { Slide cursor } \\
\text { Press key } \\
\text { Fill in empty } \\
\text { space, } \\
\text { etc. }\end{array}$ & $\begin{array}{l}\text { Solving } \\
\text { problems } \\
\text { Compare } \\
\text { fraction }\end{array}$ & $\begin{array}{l}\text { chocolate } \\
\text { bars, } \\
\text { cookies, } \\
\text { egg } \\
\text { cartons, } \\
\text { kite, } \\
\text { fractions } \\
\text { blocks, } \\
\text { coins, } \\
\text { cake, } \\
\text { Snake } \\
\text { picture, } \\
\text { etc. }\end{array}$ & $\begin{array}{l}\text { Constructivism } \\
\text { manipulative } \\
\text { Virtual } \\
\text { manipulative }\end{array}$ & $\begin{array}{l}\text { Part } \\
\text { whole } \\
\text { (area/ } \\
\text { length } \\
\text { model) } \\
\text { Part of a } \\
\text { set } \\
\text { Number } \\
\text { line }\end{array}$ & $\begin{array}{l}\text { Fraction } \\
\text { instructions } \\
\text { (researcher) } \\
\text { Read aloud } \\
\text { (researcher/ } \\
\text { students) }\end{array}$ & $\begin{array}{l}\text { Word } \\
\text { problems/ } \\
\text { questions } \\
\text { Verbalize in } \\
\text { written form } \\
\text { Crossword } \\
\text { puzzle } \\
\text { Written } \\
\text { symbols } \\
\text { (words) } \\
\text { Fraction } \\
\text { Whole } \\
\text { number } \\
\text { Decimals } \\
\text { Operations } \\
\text { Percentage }\end{array}$ \\
\hline
\end{tabular}

Outcomes of the study

The outcomes or result of the study was coded according to three categories, namely concrete, representational and abstract (CRA), representational and abstract (RA) and concrete and representational (CR). The definition for each category was applied as follows: 
1. Concrete, representational and abstract (CRA) acts as an indicator for narrative language as it links verbal and non-verbal representations (Mergenthaler \& Bucci, 1999). The sequence begins with physical objects; then continues with math symbols are transformed into pictorial representations (Fyfe \& Nathan, 2018)

2. Representational and abstract (RA) involves merely representational and abstract (RA) strategy (Flores et al., 2018) which is commonly compared to CRA in previous study (Butler, Miller, Crehan, Babbitt, and Pierce, 2003). Butleret al., (2003) study indicates that both RA and CRA intervention groups made significant progress.

3. Concrete and representational (CR) involves only concrete and representational (CR) methods which is similar to concreteness fading when concrete transforms to representation in Ching and $\mathrm{Wu}$ (2019).

\section{Result}

\subsection{Instructional focus}

All except one study (i.e., Hamdan \& Gunderson, 2017) emphasized on both conceptual and procedural knowledge. Conceptual knowledge was identified in the studies as students were required to compare fractions, find fractions magnitude using the number line, respond to fractions label correctly, use reasoning and answer word problems. On the other hand, procedural knowledge in these studies focused on the strategies of labelling, making, shading, arranging, writing, drawing, matching, naming, and comparing as the aids for solving problems. The procedures of computation and fractions operations were emphasized in Flores et al. (2018)'s study.

\subsection{Representations elements}

Real-world situation

In all except two studies (i.e., Hamdan \& Gunderson, 2017; Resnick et al., 2016), reallife scenarios were utilized to present the problems. For the educational domain, pencil scenario was utilized to determine fractions (Kaminski \& Sloutsky, 2020). For the public domain, eating chocolate (Begolli et al., 2020) and two snakes story with different lengths (Degrande et al., 2017) were employed. Whilst, personal domain involves sharing a cake with a friend (Liu, 2017); the occupational domain includes 
making cupcakes (Flores et al., 2018).

\section{Manipulative aids}

Out of seven studies utilizing manipulative aids, five studies applied multiple domains such as educational domain (e.g., paper, fraction blocks, pre-cut pieces of paper, jelly beans), occupational domain (e.g., technology tools), or public domain (e.g., kite, coins, cake, chocolate bar, egg carton, cookies) (Flores et al., 2018; Kaminski \& Sloutsky, 2020; Liu, 2017; Hamdan \& Gunderson, 2017; Resnick et al., 2016). Other two studies employed a single domain particularly educational domain (e.g., task, assessment, pencil and paper) (Begolli et al., 2020; Degrande et al., 2017).

\section{Pictures}

Meanwhile, five studies applied number line representations (i.e., Begolli et al., 2020; Flores et al., 2018; Hamdan \& Gunderson, 2017; Liu, 2017; Resnick et al., 2016). In those studies, at least two picture representations were utilized consisting monochromatic pictures (e.g., circle, chain shape circle, square, linear bar diagram and snake) or colourful pictures (e.g., paper cut of pizza crusts, sauce, cheese and toppings), part of a set representations and a picture of number line or linear bar diagram which employed measurement representations. Both measurement and part of set representations were used in four studies (Begolli et al., 2020; Degrande et al., 2017; Flores et al., 2018; Resnick et al., 2016). Whereas, for part-whole representations, pictures of pizza, circle, chain shape circle and square were utilized.

\section{Spoken}

A study by Degrande et al. (2017) did not explicitly mention the utilization of spoken verbalization either from the students, teacher or researchers. Nevertheless, spoken words appear in the article since a one-to-one interview session was conducted between the researcher and the students to identify students' verbalization and reasoning. One study required the teacher to give limited fraction instructions (Liu, 2017). Meanwhile, four studies highlighted that the researchers verbalized the experiments in spoken words (Begolli et al., 2020; Flores et al., 2018; Hamdan \& Gunderson, 2017; Kaminski \& Sloutsky, 2020). Therefore, five studies employed students verbalization in the spoken form such as reading aloud the words, reading the instructions or repeating the information and counting together with the researchers (Begolli et al., 2020; Flores et al., 2018; Hamdan \& Gunderson, 2017; Liu, 
2017; Resnick et al., 2016).

\section{Written symbols}

First is the words. Five studies applied word problems for students' intervention (Begolli et al., 2020; Degrande et al., 2017; Flores et al., 2018; Kaminski \& Sloutsky, 2020, Liu, 2017). However, all studies required students to use written symbols for words in problem-solving questions, verbalize the words in written form, perform crossword puzzle: match the words provided and list written words.

Second is the number. All seven studies used symbolic numbers such as fractions, decimals, percentages and whole numbers. Two studies specifically utilized a single form of symbolic numbers such as fractions (Kaminski \& Sloutsky, 2020) or whole numbers (Degrande et al., 2017). While, the other five studies employed at least two representations of symbolic numbers consisting of whole numbers, fractions, decimals or percentages. It was also noted that four studies associated whole numbers and fractions using number lines especially to assess students' magnitude understanding (Begolli et al., 2020; Flores et al., 2018; Hamdan \& Gunderson, 2017; Liu, 2017). Additionally, two studies involved fraction operation such as multiplication, division and addition of fractions in the studies (Flores et al., 2018; Resnick et al., 2016). The instructional focus and representations elements are highlighted in Table 4 and Table 5.

\subsection{Outcomes of each study}

Concrete, representational and abstract (CRA)

Two studies employed CRA method (Flores et al., 2018; Degrande et al., 2017). First, Flores et al., (2018) utilized different materials for each level of concreterepresentational-abstract (CRA) instruction. It was discovered that the graduated sequence of CRA is an effective strategy for developing students' conceptual understanding. Second, Degrande et al., (2017) identified children's preference reasoning strategy that is additive or multiplicative by asking which of two snakes shown had grown the most. The children were requested to verbally explain their reasoning twice; first, after picture presentation of two snakes with different lengths for the first time and later, the presentation of the same picture after a certain period. In comparing this continuous type, children's answers much explicitly verbalized the discrete items (Degrande et al., 2017). 
Representational and abstract $(R A)$

Using pretest-training-posttest design, Hamdan and Gunderson (2017) examined children's fraction learning in three ways: non-numerical control, the number line training and the area model training.

The results indicate that only number line training led children to correctly answer tasks related to magnitude understanding. Even at the initial training stage, the number line group improved at representing fractions with a number line and area model group improved at representing fractions with area models (Hamdan and Gunderson, 2017).

Meanwhile, Liu (2017) examined two different types of fractions instruction, namely limited and primary formal. Whilst, limited instruction class taught about $\frac{1}{2}$, name fraction, concrete and real-life situation and pictorial visual aids; primary instruction class introduced the concepts, definitions and meanings and fractions comparisons using symbolic number. The result indicates fraction representation among children with limited fraction instruction, was linear and understanding of fraction magnitude was related to both whole number knowledge and approximate number system (ANS).

The third is a longitudinal study by Resnick et al. (2016), who assessed the development of fraction number line estimation between $4^{\text {th }}$ and $6^{\text {th }}$ grades, identified number line estimation is essential to mathematical development (Resnick et al., 2016). Therefore, Hamdan and Gunderson (2017), Liu (2017) and Resnick et al., (2016) contributed to representational and abstract representation.

\section{Concrete and representational (CR)}

Two studies explored concrete and representational (CR) strategy (Begolli et al., 2020; Kaminski \& Sloutski, 2020). Begolli et al. (2020) indicated that discretized formats were more challenging than the continuous ones; whereas discrete formats were harder. Their intervention was executed by assigning children with either continuous, discretized, or discrete spatial representations tasks. Whilst, an example of continuous format is a picture of liquid in a beaker; an example of discretized format is a picture of a beaker with unit marking (Begolli et al., 2020).

On the other hand, Kaminski and Sloutski (2020) examined two groups of students; the first is contextualized-then-generic group and the second is genericthen-contextualized group. The result indicates that the initial instruction should begin with a simple, generic and pre-made material followed by colourful and 
contextualized representations including those made by the students (Kaminski \& Sloutsky, 2020). Even though, Kaminski and Sloutsky's (2020) study identified the representational method first followed by concrete methods (RC), it was considered as utilizing CR method. The outcomes of the studies are highlighted in Table 3.

Table 3. The outcomes of the study.

\begin{tabular}{|c|c|c|c|c|}
\hline \multicolumn{5}{|c|}{ Multiple representations } \\
\hline Lesh (1979) & $\begin{array}{l}\text { Flores et al. } \\
\text { (2018), Hwang } \\
\text { et. al. (2018), } \\
\text { Miller and } \\
\text { Hudson (2007) }\end{array}$ & CRA & RA & $\mathrm{CR}$ \\
\hline Real world & Concrete & \multirow{3}{*}{$\begin{array}{l}\text { Graduated } \\
\text { sequence of CRA } \\
\text { is effective for } \\
\text { developing } \\
\text { students' } \\
\text { conceptual } \\
\text { understanding } \\
\text { (Flores, Hinton \& } \\
\text { Taylor, 2018) } \\
\text { Children's } \\
\text { answers were } \\
\text { more often } \\
\text { explicitly } \\
\text { verbalized in } \\
\text { discrete than } \\
\text { continuous } \\
\text { items } \\
\text { (Degrande, Van } \\
\text { Hoof, } \\
\text { Verschaffel, \& } \\
\text { Van Dooren, } \\
\text { 2017) }\end{array}$} & \multirow{3}{*}{$\begin{array}{l}\text { In children with limited } \\
\text { fraction instruction, } \\
\text { fraction representation was } \\
\text { linear and fraction } \\
\text { magnitude understanding } \\
\text { was concurrently related to } \\
\text { both approximate number } \\
\text { system (ANS) and whole } \\
\text { number knowledge (Liu, } \\
\text { 2017) } \\
\text { Number line (NL) training } \\
\text { led to correct answer in } \\
\text { magnitude task which } \\
\text { implies NL is important for } \\
\text { children magnitude } \\
\text { understanding (Hamdan \& } \\
\text { Gunderson, 2017) } \\
\text { Fraction magnitude } \\
\text { understanding through } \\
\text { number line estimation is } \\
\text { found to be central to } \\
\text { mathematical development } \\
\text { (Resnick et al., 2016) }\end{array}$} & \multirow[b]{2}{*}{$\begin{array}{l}\text { Initial instruction } \\
\text { should begin with a } \\
\text { simple, generic and } \\
\text { pre-made material } \\
\text { followed by } \\
\text { colourful and } \\
\text { contextualized } \\
\text { representations } \\
\text { including those } \\
\text { made by the } \\
\text { students (Kaminski } \\
\text { \& Sloutsky, 2020) } \\
\text { Discretized formats } \\
\text { were more } \\
\text { challenging than } \\
\text { the continuous } \\
\text { ones; as predicted, } \\
\text { discrete formats } \\
\text { were harder } \\
\text { (Begolli, Booth, } \\
\text { Holmes, \& } \\
\text { Newcombe, 2020) }\end{array}$} \\
\hline $\begin{array}{l}\text { Manipulative } \\
\text { aids and } \\
\text { picture }\end{array}$ & Representational & & & \\
\hline $\begin{array}{l}\text { Spoken and } \\
\text { written } \\
\text { symbols }\end{array}$ & Abstract & & & \\
\hline
\end{tabular}


MOHAMED ET AL. (2021)

Table 4. The instructional focus and representation elements

\begin{tabular}{|c|c|c|c|c|c|c|c|c|c|}
\hline \multirow[t]{2}{*}{ Study } & \multirow[t]{2}{*}{ Year } & \multicolumn{2}{|c|}{ Instructional focus } & \multirow{2}{*}{$\begin{array}{l}\text { Real world } \\
\text { situation }\end{array}$} & \multirow[t]{2}{*}{ Manipulative aids } & \multirow[t]{2}{*}{ Pictures } & \multirow[t]{2}{*}{ Spoken } & \multicolumn{2}{|c|}{ Written symbols } \\
\hline & & Procedural & Conceptual & & & & & words & number \\
\hline $\begin{array}{l}\text { Kaminski \& } \\
\text { Sloutsky, } \\
2020\end{array}$ & 2020 & $\begin{array}{l}\text { Make } \\
\text { Cut } \\
\text { Fold } \\
\text { Explore } \\
\text { pattern } \\
\text { Label } \\
\text { Shade } \\
\text { Glue }\end{array}$ & Solve word problems & $\begin{array}{l}\text { Real-world } \\
\text { situation: two } \\
\text { chocolate bars, } \\
\text { sets of cookies, } \\
\text { empty egg } \\
\text { cartons, kite }\end{array}$ & $\begin{array}{l}\text { Make a kite of different coloured sections, } \\
\text { make a number line. Cut strips of paper. } \\
\text { Fold the strips into different proportions. } \\
\text { Explore pattern blocks. Make pizza out of } \\
\text { paper, make paper quilts by colouring (or } \\
\text { pasting) equal-sized geometric. Parts of a } \\
\text { square. Egg cartons, chocolate bar and } \\
\text { cookies. Label the proportion of pizza } \\
\text { remaining. Label proportion of the circle } \\
\text { that is shaded. Art activity- In the student- } \\
\text { made art condition, participants assembled } \\
\text { and glued pre-cut pieces of paper } \\
\text { resembling pizza crusts, sauce, cheese, and } \\
\text { toppings. In the pre-made generic condition, } \\
\text { participants assembled and glued pre-cut } \\
\text { geometric shapes onto rectangular paper. } \\
\text { Labelling proportion that matched the } \\
\text { fraction. }\end{array}$ & $\begin{array}{l}\text { Fraction models: } \\
\text { colourful, } \\
\text { contextualized } \\
\text { student } \\
\text { constructed } \\
\text { material (paper } \\
\text { pizza), simple pre- } \\
\text { made material } \\
\text { (monochromatic } \\
\text { paper circles). } \\
\text { The order was } \\
\text { counterbalanced } \\
\text { across questions. } \\
\text { the picture of } \\
\text { pizza/circles } \\
\text { divided into } \\
\text { equally sized slices }\end{array}$ & $\begin{array}{l}\text { The researcher } \\
\text { read the } \\
\text { questions one } \\
\text { at a time }\end{array}$ & $\begin{array}{l}\text { Word } \\
\text { problems }\end{array}$ & $\begin{array}{l}\text { Fraction } \\
\text { knowledge. } \\
\text { Labelling } \\
\text { proportion; } \\
\text { there were four } \\
\text { types of } \\
\text { responses: } \\
\text { correct answer, } \\
\text { correct } \\
\text { numerator/ } \\
\text { incorrect } \\
\text { denominator, } \\
\text { correct } \\
\text { denominator/ } \\
\text { incorrect } \\
\text { numerator and } \\
\text { incorrect } \\
\text { numerator/ } \\
\text { incorrect } \\
\text { denominator. }\end{array}$ \\
\hline $\begin{array}{l}\text { Begolli, } \\
\text { Booth, } \\
\text { Holmes, \& } \\
\text { Newcombe, } \\
2020\end{array}$ & 2020 & Shade & $\begin{array}{l}\text { Fraction words (half, a } \\
\text { quarter, two quarters, } \\
\text { a third, three } \\
\text { quarters, and an } \\
\text { eighth), which were } \\
\text { displayed at the } \\
\text { halfway point on top } \\
\text { of the number line } \\
\text { Indicate fraction's } \\
\text { location on a number } \\
\text { line. Compare } \\
\text { fractions }\end{array}$ & Real-life situation & $\begin{array}{l}\text { Paper-and-pencil-based proportional } \\
\text { equivalence task and mathematics } \\
\text { assessment. } \\
\text { Shade an area based on a fraction. } \\
\text { Shaded area with symbolic fraction } \\
\text { notation. } \\
\text { Fraction subtraction ( } 6 \text { items), division ( } 1 \\
\text { item), comparison ( } 5 \text { items), and part- } \\
\text { whole. } \\
\text { Picture -- } \rightarrow \text { symbol representation ( } 1 \text { item). }\end{array}$ & $\begin{array}{l}\text { Part-whole and } \\
\text { number line, } \\
\text { number line was } \\
\text { labelled at each } \\
\text { end point with } 0 \\
\text { and } 1 . \\
\text { Picture of } \\
\text { rectangle. } \\
\text { Chain shape circle. }\end{array}$ & $\begin{array}{l}\text { Children read } \\
\text { the } \\
\text { instructions } \\
\text { together with } \\
\text { the researcher }\end{array}$ & $\begin{array}{l}\text { Word } \\
\text { problems }\end{array}$ & $\begin{array}{l}\text { Whole number } \\
\text { Fractions }\end{array}$ \\
\hline $\begin{array}{l}\text { Flores, } \\
\text { Hinton \& } \\
\text { Taylor, } 2018\end{array}$ & 2018 & $\begin{array}{l}\text { Follow CRA } \\
\text { activity }\end{array}$ & $\begin{array}{l}\text { Solve word problems } \\
\text { at abstract level }\end{array}$ & Real-life problems & $\begin{array}{l}\text { Manipulative: } \\
\text { Concrete }(C)=\text { Sheets, fraction tiles, fractions } \\
\text { blocks, number lines, and coins } \\
\text { Representation }(R)=\text { Sheets with } \\
\text { equipartitioned shapes and number lines, } \\
\text { number lines with pictures of coins; }\end{array}$ & $\begin{array}{l}\text { Area model } \\
\text { Length model } \\
\text { Number line }\end{array}$ & $\begin{array}{l}\text { The researcher } \\
\text { gave explicit } \\
\text { instruction, } \\
\text { students } \\
\text { repeated } \\
\text { information }\end{array}$ & $\begin{array}{l}\text { Word } \\
\text { problems }\end{array}$ & $\begin{array}{l}\text { Fractions } \\
\text { Whole number } \\
\text { Computation } \\
\text { Decimals } \\
\text { Equivalent and }\end{array}$ \\
\hline
\end{tabular}


and count with

the

researcher.

think aloud

about parts of

the problem

\begin{tabular}{llll}
\hline Liu, 2017 2017 & $\begin{array}{l}\text { Make } \\
\text { Name }\end{array}$ & $\begin{array}{l}\text { Solve word problems, } \\
\text { Compare fractions }\end{array}$ & Real-life scenarios \\
\end{tabular}

Concrete:

Cake, whole number line estimation task

and number line estimation task.

Make one clear mark on number line
Linear fraction Limited

ractions

picture, visual aids, instructions

number line

(researcher)

square

Name and

Problem Fraction

solving Decimal

questions Percentage

compare

fractions.

Students'

reading

achievement

\begin{tabular}{|c|c|c|}
\hline $\begin{array}{l}\text { Degrande, } \\
\text { Van Hoof, } \\
\text { Verschaffel, } \\
\& \text { Van } \\
\text { Dooren, } \\
2017\end{array}$ & 2017 & Writing \\
\hline $\begin{array}{l}\text { Hamdan \& } \\
\text { Gunderson, } \\
2017\end{array}$ & 2016 & $\begin{array}{l}\text { Draw } \\
\text { Shade } \\
\text { Writing } \\
\text { Matching }\end{array}$ \\
\hline
\end{tabular}

$\begin{array}{llll}\begin{array}{l}\text { Additive and } \\ \text { multiplicative }\end{array} & \text { Problem } & \text { Non-symbolic snake task } & \text { Snake picture in } \\ \text { reasoning } & \text { situations } & \text { Pencil-and-paper test } & \begin{array}{l}\text { discrete and } \\ \text { continuous tasks }\end{array}\end{array}$

Draw number line and circle segment, shade

the parts and writing fractions

Online supplement materials for the training

The number line

and circle,

Children rea

subsequent

clues aloud.

Systematic

instruction,

Direct

instructions

(experimenter

explanation)

\begin{tabular}{llll}
\hline $\begin{array}{l}\text { Resnick et } \\
\text { al., 2016 }\end{array}$ & $\begin{array}{l}\text { Use arrow } \\
\text { keys } \\
\text { Slide cursor } \\
\text { Press key }\end{array}$ & $\begin{array}{l}\text { Solve multiplication } \\
\text { problems }\end{array}$ \\
& $\begin{array}{l}\text { Wholl in empty } \\
\text { space }\end{array}$ & $\begin{array}{l}\text { fractions estimation } \\
\text { on a number line to } \\
\text { assess fraction } \\
\text { magnitude } \\
\text { understanding }\end{array}$ \\
& &
\end{tabular}

Paper and pencil presentation and

Reading

Number line

fluency: read

Whole number

model estimation task

Estimated the locations of 28 fractions and

mixed numbers on a laptop: use arrow keys,

slide the cursor along number line and press

different key. Fill in the empty space.

presented on

aloud

verbalize

Whole number

form

Shaded sections of a polygon or set of

polygons. Computer-based multiple-choice

Polygon or set of

polygons

Cross Fractions

word

Fractions

puzzle:

on number line

understanding

test.

Teachers rated children's attention during

mathematics classes. 
MOHAMED ET AL. (2021)

Table 5. Metadata analysis of the instructional focus and representation elements

\begin{tabular}{|c|c|c|c|c|c|c|c|c|c|c|c|c|c|c|c|c|c|c|c|c|c|}
\hline \multirow[t]{3}{*}{ Study } & \multirow[b]{3}{*}{$\stackrel{\frac{1}{\pi}}{\stackrel{1}{\nearrow}}$} & \multicolumn{3}{|c|}{$\begin{array}{l}\text { Instructional } \\
\text { focus }\end{array}$} & \multirow{2}{*}{\multicolumn{2}{|c|}{ 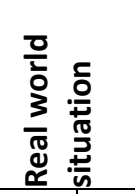 }} & \multirow{2}{*}{\multicolumn{4}{|c|}{ Manipulative aids }} & \multirow{2}{*}{\multicolumn{3}{|c|}{ Pictures }} & \multirow{2}{*}{\multicolumn{2}{|c|}{$\begin{array}{l}\frac{c}{d} \\
\frac{y}{0} \\
\text { n் }\end{array}$}} & \multicolumn{6}{|c|}{ Written symbols } \\
\hline & & \multirow[b]{2}{*}{$\begin{array}{l}\bar{T} \\
\frac{0}{2} \\
0 \\
\stackrel{0}{0} \\
0 \\
0\end{array}$} & \multicolumn{2}{|c|}{ 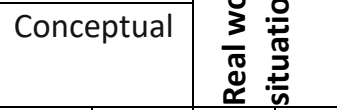 } & & & & & & & & & & & & \multirow[b]{2}{*}{$\frac{n}{0}$} & \multicolumn{5}{|c|}{ number } \\
\hline & & & $\begin{array}{l}\varepsilon \\
\frac{\varepsilon}{0} \\
0 \\
0 \\
0 \\
0 \\
0 \\
3 \\
0 \\
0 \\
0\end{array}$ & 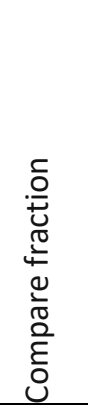 & 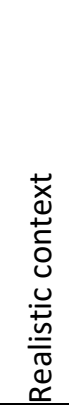 & 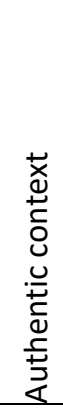 & 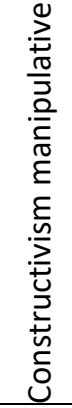 & 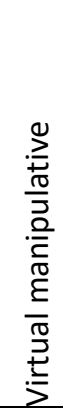 & 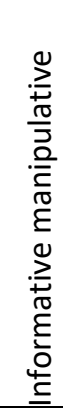 & 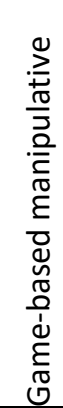 & 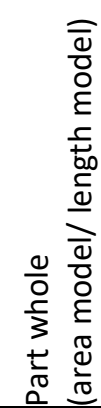 & 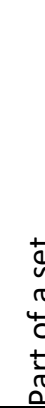 & 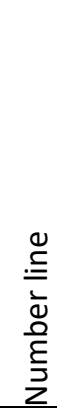 & 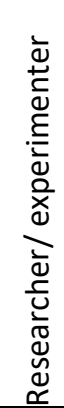 & 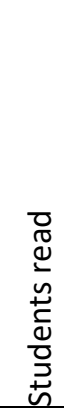 & & $\begin{array}{l}\frac{5}{0} \\
\frac{0}{0} \\
\frac{\pi}{4}\end{array}$ & 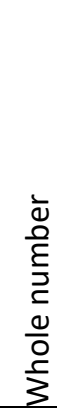 & $\begin{array}{l}\frac{\pi}{0} \\
\frac{E}{U} \\
\frac{d}{0}\end{array}$ & $\begin{array}{l}n \\
\frac{n}{0} \\
.0 \\
\frac{0}{0} \\
\frac{0}{d} \\
0 \\
0\end{array}$ & 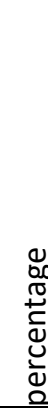 \\
\hline Kaminski and Sloutsky, 2020 & 2020 & 1 & 1 & 0 & 1 & 0 & 1 & 0 & 0 & 0 & 1 & 1 & 0 & 1 & 0 & 1 & 1 & 0 & 0 & 0 & 0 \\
\hline Begolli et al., 2020 & 2020 & 1 & 1 & 1 & 1 & 0 & 1 & 0 & 0 & 0 & 1 & 1 & 1 & 1 & 1 & 1 & 1 & 1 & 0 & 0 & 0 \\
\hline Flores et la., 2018 & 2018 & 1 & 1 & 0 & 1 & 0 & 1 & 0 & 0 & 0 & 1 & 0 & 1 & 1 & 1 & 1 & 1 & 1 & 1 & 1 & 0 \\
\hline Liu, 2017 & 2017 & 1 & 1 & 1 & 1 & 0 & 1 & 0 & 0 & 0 & 1 & 0 & 1 & 1 & 1 & 1 & 1 & 1 & 1 & 0 & 1 \\
\hline Degrande et al., 2017 & 2017 & 1 & 1 & 0 & 1 & 0 & 1 & 0 & 0 & 0 & 1 & 1 & 0 & 0 & 0 & 1 & 0 & 1 & 0 & 0 & 0 \\
\hline Hamdan and Gunderson, 2017 & 2016 & 1 & 0 & 0 & 0 & 0 & 1 & 0 & 0 & 0 & 1 & 0 & 1 & 1 & 1 & 1 & 1 & 1 & 0 & 0 & 0 \\
\hline Resnick et al., 2016 & 2016 & 1 & 0 & 1 & 0 & 0 & 0 & 1 & 0 & 0 & 1 & 1 & 1 & 0 & 1 & 1 & 1 & 0 & 0 & 1 & 0 \\
\hline TOTAL & & 7 & 5 & 3 & 5 & 0 & 6 & 1 & 0 & 0 & 7 & 4 & 5 & 5 & 5 & 7 & 6 & 5 & 2 & 2 & 1 \\
\hline
\end{tabular}

Note: 1 stands for appear and 0 for does not appear in the article. 
The purpose of present study is to identify the characteristics, instructional focus, representation elements and the outcomes of each study. The selected studies emphasize on procedural knowledge, symbolic words, and part whole representations especially the area and length models. However, most previous studies focused on both procedural and conceptual knowledge of which most representations use realistic context and constructivism manipulative aids. In fact, the students were encouraged to speak through reading or verbally respond to the researcher's one-toone task-based interview. Finally, the three highest consecutive symbolic representations employed were symbolic words, symbolic fraction numbers and symbolic whole numbers.

Nevertheless, comparing fractions using part of a set (Begolli et al., 2020; Resnick et al., 2016), learning aids that encourage student's virtual manipulative (Resnick et al., 2016) and connecting with either symbolic decimals (Flores et al., 2018; Liu, 2017), operations (Flores et al., 2018; Resnick et al., 2016), or percentage numbers were lacking (Liu, 2017). According to Tsai and Li (2016), connecting fractions with decimals and percentages is important to help students moving among the concepts flexibly and efficiently in dealing with daily life situation. Besides, none of the selected studies were related to authentic problem context such as problem- or project-based learning (PBL) which was consistent with the result by Minarni, Napitupulu and Husein (2016). They discovered that conventional approach was still practiced for Indonesian students and class engagement activity was low as well as the students' mastery achievement and performance were low. Furthermore, none of the studies carried out informative manipulative method, which implies that those studies paid serious attention to the students' construction meaning (Fyfe \& Nathan, 2018). In addition, game-based manipulative was not utilized to teach fractions for understanding.

More specific discussions for each focus question are presented accordingly. First, the study characteristics were summarized into participants' context and settings. Both demographic characteristics are important indicators for effective teaching mathematics; whereby students' various backgrounds and characteristics with teachers' different set of plans are demonstrated (Brophy \& Good, 1986). Almost all studies explicitly demonstrate the participants' characteristics, grade, ethnicity, urbanicity and location which mostly directed from Western countries. It was discovered that those elementary schools emphasize on teaching fractions through 
representations with various targeted urbanicity. However, the location should be wider. East Asian countries may highlight different approaches for representations of fractions and specific instructional focus for students with various cultures and demographic backgrounds.

Second, most mathematics education researchers paid serious attention to connecting procedural with conceptual knowledge in teaching fractions (Begolli et al., 2020; Degrande et al., 2017; Flores et al., 2018; Kaminski \& Sloutsky, 2020; Liu, 2017; Resnick et al., 2016). Roesslein and Codding (2019) emphasized both to develop a strong foundation on fraction concept and problem-solving ability. Therefore, emphasis should be given on both procedural and conceptual knowledge of fractions at the early years of schooling (Agrawal \& Baker, 2013; Turner, 2011) including kindergarten level.

Third, the present review analyzed the representation elements adapted in these studies related to instructional fractions extended from Roesslein \& Codding's (2019) review on instructional components and Behr et al.'s (1983) interactive representational model. The articles were coded for the representation elements applied such as (a) real-world situation; (b) manipulative aid; (c) pictures; (d) spoken; and (e) written symbols (words and number). All seven studies utilized multiple representations with different approaches whereby manipulative aids and pictures were the compulsory elements. Multiple representations not only limited between representation elements such as simple, generic, pre-made material (picture) and colorful, contextualized (realistic context) representations (Kaminski \& Sloutsky, 2020) but also within representations which emphasized on explicit characteristics of the picture such as discrete, discretized or continuous format (Begolli et al., 2020). Although two studies (Hamdan \& Gunderson, 2017; Resnick et al., 2016) did not utilize real-life problems in their intervention, the remaining five studies emphasized real-life situations in problems presented to students. This shows that real-life problem is an important representation element for teaching fraction through representations.

Furthermore, real-world situation and manipulative aids are critical in shaping learner's performance and understanding (Penalvo, 2008, p. 134) of fractions by offering a deep-set and large of sensory experience (Bartolini \& Martignone, 2014). Besides, both elements are also related to the choices of educational domain, personal domain, public domain and occupational domain in problem solving task (Council of Europe, 2011). When students are familiar with the selected domain such as personal 
domain and educational domain, the students feel encouraged to express ideas in their own words and teacher could ask the students to respond (Patahuddin, Usman, \& Ramful, 2017). If the domain is unfamiliar to the students such as occupational domain and public domain, it benefits them in the opposite as it prepares them for future job demand when they apply conceptual knowledge in novel situation (Kaminski \& Sloutsky, 2020) and enhance their higher thinking skills. However, it still depends on the students' abilities and the outcomes that the teacher or researcher aims to develop.

Spoken representation is an important element to encourage students' response and develop interpersonal skills (Vygotsky, 1978). Typically, elementary students are trained with communication skills before they are asked to write in words. However, in current study spoken representation is emphasized less than the verbalization in written form. Additionally, it is suggested for future researches to observe the effects of both elements on students' communications skills and understanding fractions. Therefore, it is hoped that fractions difficulty and misconception can be overcome not only among elementary students but also among upper-grade level and up to higher education students as it has been highlighted for the past three decades (Behr et al., 1983; Hoch, Reinhold, Werner, Richter-Gebert, \& Reiss, 2018).

One of the reasons for fractions difficulty is due to its various definitions. It is shown in this review that the representations of fractions appear in a symbolic number of fractions (numerator over denominator), decimals or percentages. However, the symbolic numbers were utilized in most of the reviewed studies also involve whole numbers, especially when a number line was applied. Utilized number line could overcome whole number bias in fractions interpretation. It is evident in five studies as demonstrated by the usage of symbolic number of fractions and whole numbers through a number line.

Fourth, the outcomes identified in each selected study are related to CRA method by Miller and Hudson (2007), Flores et al. (2018) and Hwang et. al. (2018). The emphasis is given on gradual sequence between concrete, representational and abstract, whereby students personally were given an opportunity to first-hand experience using hands-on manipulative task (Flores et al., 2018). The sequence also occurs from representational phase as in a simple, generic and pre-made material to concrete phase as in the colourful and contextualized representations (Kaminski \& Sloutsky, 2020). In addition, the sequence begins from representational phase to abstract phase as in using a number line and estimating the value on a number line 
(Resnick et al., 2016), utilizing number line to magnitude tasks (Hamdan \& Gunderson, 2017) and using representations for approximate number system (ANS) and whole number knowledge (Liu, 2017). This shows that the transformation of representations is a flexible process (Deliyianni, Gagatsis, Elia \& Panaoura, 2015) because it does not necessarily begin with the concrete phase; instead begins with representations phase to concrete phase.

The results also imply that at the initial phase of teaching fractions, students should be taught explicit translation methods from concrete or representational or abstract representations, explicit use of number line to compare fractions and integration use of representational characteristics such as discretized, discrete, and continuous formats. Therefore, multiple representations are not necessary to be used in sequence or connected to students' age (Hoch et al., 2018). As supported by Flores, Inan, Han and Koontz (2018), students learning is enhanced when multiple representations are parallelly utilized. However, the priority is to expose students to multiple representations of the same concept Fyfe and Nathan (2015).

\subsection{Limitations and recommendations}

The primary limitation of current review is the sole use of Web of Science database which was accessed via Universiti Sains Malaysia platform. The utilization of a single database restricts the researchers from obtaining articles from different languages, fields and journals available around the world (Falagas, Pitsouni, Malietzis, \& Pappas, 2008). Next, small sample ( $n=7$ ) was included. Nevertheless, the content analysis was conducted with care particularly in interpreting the results and developing confidence of the findings.

Since future research on teaching fractions among elementary students is important, instruction coding focuses on operational definitions of conceptual and procedural knowledge adapted from previous studies (Anderson, et al., 2001, p. 46; Misquitta, 2011; Roesslein \& Codding, 2019). Therefore, the definitions may differ in different studies. The authors in current review coded the criteria for the knowledge accordingly but did not explicitly relate how the codes affect fractions understanding. Hence, this springs out the suggestion for future study. In coding representation elements, the authors relied on the descriptions in abstract, methodology and results in particular the procedures, measures and figures related to fractions. Figures and verbalization in written form are useful guidance to obtain necessary codings for the respective representation elements in the review. 


\subsection{Practical implications}

The findings from this current review suggest several instructional implications for educators, teachers, curriculum developers, textbooks writers and researchers. First, fraction interventions that utilize multiple representation elements should be sequentially or parallelly employed to enhance students' understanding of the same concept related to fractions. Moreover, it provides choices of selected measures and procedures available to future researchers interested in representations for fraction learning. In fact, it can be an alternative strategy for teachers to overcome the misconception among students by exposing students to explicit use of representational characteristics. In addition, variations within representation such as part of a set, part-whole of an object and measurement representation are essential in developing students' understanding pertaining to fractions. All types of picture representations are closely related. Whilst a set is a group of an object; a number line is a measurement representation which is significant in assessing students' magnitude understandings. It assists students to differentiate fractions with the whole numbers. Therefore, more researches should explore the combination of all types of representations for teaching and learning fractions.

\subsection{Conclusions}

The current review provides the most recent evidence in the representation elements for teaching fractions in terms of study characteristics, instructional focus, representation elements and fractions research outcomes. While considering the limitations, the analysis outcomes offer teachers or researchers guidance on how to decrease misconception towards fractions from as early as elementary level students; while, providing a strong foundation for future challenging topics in Mathematics. This review provides a systematic PRISMA procedure as a direction for future researches; in particular for those interested in the review about fractions and possibly those in other fields.

\section{References}

Agrawal, J. (2013). The effects of explicit instruction with manipulatives on the fraction skills of students with autism (George Mason University). http://login.ezproxy.lib.umn.edu/

Aliustaoğlu, F., Tuna, A., \& Biber, A. Ç. (2018). Misconceptions of Sixth Grade Secondary School Students on Fractions. Journal of Elementary Education, 10(5), 591-599.

https://doi.org/10.26822/iejee.2018541308 
Anderson, L. W., Krathwohl, D. R., Airasian, P. W., Cruikshank, K. A., Mayer, R. E., Pintrich, P. R., ... Wittrock, M. C. (2001). A taxonomy for learning, teaching, and assessing: A revision of Bloom's taxonomy of educational objectives. United States: Addison Wesley Longman, Inc.

Bailey, D. H., Zhou, X., Zhang, Y., Cui, J., Fuchs, L. S., Jordan, N. C., ... Siegler, R. S. (2015). Development of fraction concepts and procedures in U.S. and Chinese children. Journal of Experimental Child Psychology, 129, 68-83. https://doi.org/10.1016/j.jecp.2014.08.006

Bartolini, M. G., \& Martignone, F. (2014). Encyclopedia of Mathematics Education. In Encyclopedia of Mathematics Education. https://doi.org/10.1007/978-94-007-4978-8

Begolli, K. N., Booth, J. L., Holmes, C. A., \& Newcombe, N. S. (2020). How many apples make a quarter? The challenge of discrete proportional formats. Journal of Experimental Child Psychology, 192, 1-20. https://doi.org/10.1016/j.jecp.2019.104774

Behr, M. J., Lesh, R., Post, T. R., \& Silver, E. A. (1983). Rational-Number Concepts *. ResearchGate, (June), 91-125. https://www.researchgate.net/publication

Booth, J. L., Newton, K. J., \& Twiss-Garrity, L. K. (2014). The impact of fraction magnitude knowledge on algebra performance and learning. Journal of Experimental Child Psychology, 118(1), 110-118. https://doi.org/10.1016/j.jecp.2013.09.001

Braithwaite, D. W., Leib, E. R., Siegler, R. S., \& McMullen, J. (2019). Individual differences in fraction arithmetic learning. Cognitive psychology, 112, 81-98. https://doi.org/10.1016/j.cogpsych.2019.04.002

Brophy, J., \& Good, T. (1986). Teacher behavior and student achievement. In M. C. Wittrock (Ed.), Handbook of research on teaching (3rd ed.). New York: McMillan.

Bruner, J. S. (1971). Toward a theory of instruction (5th ed). Cambridge, Massachusetts: Harvard University Press.

Burnham, J. F. (2006). Scopus database: A review. Biomedical Digital Libraries, 3(1), 1-8. https://doi.org/10.1186/1742-5581-3-1

Chan, W. H., Leu, Y. C., \& Chen, C. M. (2007). Exploring group-wise conceptual deficiencies of fractions for fifth and sixth graders in Taiwan. The Journal of Experimental Education, 76(1), 26-57. https://doi.org/10.3200/JEXE.76.1.26-58

Council of Europe. (2011). Common European Frameworkk of Reference for languages: Leaarning, teaching, assessment (12th ed.). Cambridge, UK: Cambridge University Press.

Degrande, T., Van Hoof, J., Verschaffel, L., \& Van Dooren, W. (2017). Open word problems: Taking the additive or the multiplicative road? ZDM - Mathematics Education, 5O(1-2), 91-102. https://doi.org/10.1007/s11858-017-0900-6

Deliyianni, E., Gagatsis, A., Elia, I., \& Panaoura, A. (2016). Representational flexibility and problem-solving ability in fraction and decimal number addition: A structural model. International Journal of Science and Mathematics Education, 14(2), 397417.https://doi.org/10.1007/s10763-015-9625-6

Fan, L., \& Zhu, Y. (2007). Representation of problem-solving procedures: A comparative look at China, Singapore, and US mathematics textbooks. Educational Studies in Mathematics, 66, 61-75. https://doi.org/10.1007/s10649-006-9069-6

Fitzsimmons, C. J., Thompson, C. A., \& Sidney, P. G. (2020). Confident or familiar? The role of familiarity ratings in adults' confidence judgments when estimating fraction magnitudes. Metacognition and Learning, 15(2), 215-231. https://doi.org/10.1007/s11409-020-092259

Flores, M. M., Hinton, V. M., \& Taylor, J. J. (2018). CRA fraction intervention for fifth-grade students receiving tier two interventions. Preventing School Failure: Alternative Education for Children and Youth, 62(3), 198-213. https://doi.org/10.1080/1045988X.2017.1414027

Flores, R., Inan, F. A., Han, S., \& Koontz, E. (2018). Comparison of algorithmic and multiplerepresentation integrated instruction for teaching fractions, decimals, and percent. 
Investigations in Mathematics Learning, 11(4), 231-244.

https://doi.org/10.1080/19477503.2018.1461050

Fuchs, L. S., Schumacher, R. F., Long, J., Namkung, J., Malone, A. S., Wang, A., ... Changas, P. (2016). Effects of intervention to improve At-Risk fourth graders' understanding, calculations, and word problems with fractions. Elementary School Journal, 116(4), 625651. https://doi.org/10.1086/686303

Fyfe, E. R., \& Nathan, M. J. (2018). Making "concreteness fading” more concrete as a theory of instruction for promoting transfer. Educational Review, 71(4), 403-422.

https://doi.org/10.1080/00131911.2018.1424116

Hacker, D. J., Kiuhara, S. A., \& Levin, J. R. (2019). A metacognitive intervention for teaching fractions to students with or at-risk for learning disabilities in mathematics. ZDM Mathematics Education, 51(4), 601-612. https://doi.org/10.1007/s11858-019-01040-0

Hamdan, N., \& Gunderson, E. A. (2017). The number line is a critical spatial-numerical representtation: Evidence from a fraction intervention. Developmental Psychology, 53(3), 587-596.

Hoch, S., Reinhold, F., Werner, B., Richter-Gebert, J., \& Reiss, K. (2018). Design and research potential of interactive textbooks: the case of fractions. ZDM - Mathematics Education, 5O(5), 839-848. https://doi.org/10.1007/s11858-018-0971-Z

Hwang, J., Riccomini, P. J., Hwang, S. Y., \& Morano, S. (2018). A Systematic Analysis of Experimental Studies Targeting Fractions for Students with Mathematics Difficulties. Learning Disabilities Research and Practice, 34(1), 47-61.

https://doi.org/10.1111/ldrp.12187

Istiandaru, A., Istihapsari, V., Prahmana, R. C. I., Setyawan, F., \& Hendroanto, A. (2017). Characteristics of manipulative in mathematics laboratory. Journal of Physics: Conf. Series, 943 O12023, 1-7. https://www.researchgate.net/publication/

Kaminski, J. A., \& Sloutsky, V. M. (2020). The use and effectiveness of colorful , contextualized , student-made material for elementary mathematics instruction. International Journal of STEM Education, 7(6), 1-23.

Krowka, S. K., \& Fuchs, L. S. (2017). Cognitive profiles associated with responsiveness to fraction intervention. Learning Disabilities Research and Practice, 32(4), 216-230. https://doi.org/10.1111/ldrp.12146

Lesh, R. (1979). Mathematical learning disabilities: Considerations for identification, diagnosis, and remediation. In R. Lesh, D. Mierkiewicz, \& M. G. Kantowski, Applied mathematical problem solving (pp. 111-180). Columbus: ERIC/SMEAC.

Liberati, A., Altman, D. G., Tetzlaff, J., Mulrow, C., Gøtzsche, P. C., Ioannidis, J. P. A., ... Moher, D. (2009). The PRISMA statement for reporting systematic reviews and meta-analyses of studies that evaluate health care interventions: Explanation and elaboration. PLoS Medicine, 6(7). https://doi.org/10.1371/journal.pmed.1000100

Liu, Y. (2017). Fraction magnitude understanding and its unique role in predicting general mathematics achievement at two early stages of fraction instruction. British Journal of Educational Psychology, 88(3), 345-362. https://doi.org/10.1111/bjep.12182

Masingila, J. o., \& Moellwald, F. E. (1993). Using Polya to foster a classroom environment for realworld. School Science and Mathematics, 93(May), 245.

Miller, S. P., \& Hudson, P. J. (2007). Using Evidence-Based Practices to Build Mathematics Competence Related to Conceptual, Procedural, and Declarative Knowledge. Learning Disabilities Research \& Practice, 22(1), 47-57. https://doi.org/10.1111/j.15405826.2007.00230.x

Minarni, A., Napitupulu, E. E., \& Husein, R. (2016). Mathematical understanding and representation ability of public junior high school in North Sumatra. Journal on Mathematics Education, 7(1), 43-56. https://doi.org/10.22342/jme.7.1.2816.43-56 
Misquitta, R. (2011). A Review of the Literature: Fraction instruction for struggling learners in Mathematics. Learning Disabilities Research \& Practice, 26(2), 109-119.

https://doi.org/10.1111/j.1540-5826.2011.00330.x

National Council of Teachers of Mathematics. (2007). Second handbook of research on mathematics teaching and learning. Washington, DC: National Council of Teachers of Mathematics.

$\mathrm{Ni}, \mathrm{Y}$. (2000). How valid is it to use number lines to measure children's conceptual knowledge about rational number? Educational Psychology, 2o(2), 139-152. https://doi.org/10.1080/713663716

Patahuddin, S. M., Usman, H. B., \& Ramful, A. (2017). Affordances from Number Lines in Fractions Instruction: Students' Interpretation of Teacher's Intentions. International Journal of Science and Mathematics Education. https://doi.org/10.1007/s10763-0179800-Z

Penalvo, F. J. (2008). Andvance in e-learning: Experiences and methodologies. London, United Kingdom: IGI Global.

Pimm, D. (1995). Symbols and meanings in the school mathematics. Retrieved from http://www.whats-your-sign.com/fire-symbols-and-meanings.html

Reinhold, F., Hoch, S., Werner, B., Richter-Gebert, J., \& Reiss, K. (2020). Learning fractions with and without educational technology: What matters for high-achieving and low-achieving students? Learning and Instruction, 65(September 2019), 101264.

https://doi.org/10.1016/j.learninstruc.2019.101264

Resnick, I., Jordan, N. C., Hansen, N., Rajan, V., Rodrigues, J., Siegler, R. S., \& Fuchs, L. S. (2016). Developmental growth trajectories in understanding of fraction magnitude from fourth through sixth grade. Developmental Psychology, 52(5), 746-757. https://doi.org/10.1037/dev0000102

Roesslein, R. I., \& Codding, R. S. (2019). Fraction interventions for struggling elementary math learners: A review of the literature. Psychology in the Schools, 56(3), 413-432. https://doi.org/10.1002/pits.22196

Shaffril, H. A. M., Abu Samah, A., Samsuddin, S. F., \& Ali, Z. (2019). Mirror-mirror on the wall, what climate change adaptation strategies are practiced by the Asian's fishermen of all? Journal of Cleaner Production, 232, 104-117. https://doi.org/10.1016/j.jclepro.2019.05.262

Siegler, R. S., Thompson, C. A., \& Schneider, M. (2011). An integrated theory of whole number and fractions development. Cognitive Psychology, 62(4), 273-296. https://doi.org/10.1016/j.cogpsych.2011.03.001

Supandi, S., Waluya, S. B., Rochmad, R., Suyitno, H., \& Dewi, K. (2018). Think-talk-write model for improving abilities in mathematical representation. International Journal of Instruction, 11(3), 77-90. https://doi.org/10.12973/iji.2018.1136a

Tajudin, N. M., \& Chinnappan, M. (2016). The link between higher order thinking skills, representation and concepts in enhancing TIMSS tasks. International Journal of Instruction, 9(2), 199-214. https://doi.org/10.12973/iji.2016.9214a

Turner, S. A. (2011). Intervention on the achievement and self-efficacy beliefs. University of the Pacific Stockton.

Van Steenbrugge, H., Remillard, J., Verschaffel, L., Valcke, M., \& Desoete, A. (2015). Teaching fractions in elementary school: An observational study. The Elementary School Journal, 116(1), 49-75.

Vygotsky, L. S. (1978). Mind in society: The development of higher psychological processes. Cambbridge, Massachusetts: Harvard University Press. 